\title{
Aqueous environment as the reservoir of plant viruses
}

\section{Woda jako środowisko rozprzestrzeniania się wirusów roślin}

\author{
Małgorzata Jeżewska*
}

\section{Summary}

Studies on the detection of plant viruses in aqueous environment primarily focused on the natural sources of water, i.e. lakes, rivers and seas. The increasing deficit of water supply at the end of the last century and the necessity of water recycling prompted to analyze its microbiological quality after such process, including virus contamination. On the other hand the development of molecular diagnostic methods enhanced the sensitivity and reliability of the detection. In this paper the present state of knowledge concerning the detection of plant viruses in aqueous environment as well as methods of the virus elimination are reviewed.

Key words: plant viruses; water; occurrence; detection; risk of infection; virus elimination

\section{Streszczenie}

Badania dotyczące wykrywania wirusów roślin w środowisku wodnym początkowo koncentrowano na wodach naturalnych, takich jak: jeziora, rzeki, czy morza. Pogłębiający się pod koniec ubiegłego wieku deficyt wody spowodował konieczność wielokrotnego wykorzystywania wody po oczyszczaniu i stosowania obiegów zamkniętych sprzyjających wzrostowi koncentracji wirusów, szczególnie tych, których gospodarzami są rośliny nawadniane. Jednocześnie postęp w rozwoju molekularnych metod diagnostycznych umożliwił lepsze, bardziej precyzyjne i wiarygodne wykrywanie oraz identyfikację wirusów z wody. W niniejszej pracy omówiono aktualny stan wiedzy w zakresie wykrywania i możliwości ograniczania występowania wirusów roślin w środowisku wodnym.

Słowa kluczowe: wirusy roślin; woda; występowanie; wykrywanie; zagrożenie; eliminacja wirusów

Instytut Ochrony Roślin - Państwowy Instytut Badawczy

Władysława Węgorka 20, 60-318 Poznań

*corresponding author: m.jezewska@iorpib.poznan.pl 


\section{Wstęp / Introduction}

Badania mające na celu wykrywanie wirusów w środowisku wodnym początkowo koncentrowano głównie na patogenach groźnych dla człowieka, wśród których najważniejszymi są: wirus polio, wirusy wątroby typu A i E, Coxsackie, enterowirusy, adenowirusy, reowirusy, rotawirusy i kaliciwirusy. Wolf (2015) przedstawiła zagrożenie i możliwości kontroli tych wirusów.

W latach 60. zwrócono uwagę na ryzyko zakażeń wirusami roślin pochodzącymi $\mathrm{z}$ wody (WB - water-borne), a niewymagającymi przenoszenia przez wektory. Pionierską pracę dotyczącą uwalniania wirusów tytoniu: mozaiki (Tobacco mosaic virus, TMV) i nekrozy tytoniu (Tobacco necrosis virus, TNV), z korzeni roślin do rowów melioracyjnych, a tym samym generowanie łańcucha zakażeń, opublikował Yarwood (1960).

W latach 80. ubiegłego wieku rozwinięto badania nad wirusami obecnymi we wszelkich rodzajach wód, przede wszystkim naturalnych: morzach, rzekach, jeziorach, stawach, kanałach nawadniających i rowach melioracyjnych. W następnych latach pojawił się nasilający problem światowego deficytu wody (Riley i wsp. 2011), w związku z czym rozpowszechniono wykorzystywanie w szklarniach i szkółkach wody oczyszczanej w obiegu zamkniętym. Wyłoniła się zatem konieczność oceny czystości mikrobiologicznej wody w systemie wielokrotnego użytku po tzw. recyklingu.

Tradycyjne metody wykrywania wirusów w wodzie, obejmujące etapy: zagęszczania, inokulacji mechanicznej roślin testowych oraz dalszej klasycznej diagnostyki wirusologicznej okazały się niewystarczające ze względu na ograniczoną czułość detekcji.

Pojawianie się wciąż udoskonalanych metod diagnostyki molekularnej stymuluje tego typu badania. Wymagania dotyczące nowych metod obejmują zarówno wysoką specyficzność, czułość, szybkość, jak i dostępność ekonomiczną. Najpowszechniej stosowaną metodą jest łańcuchowa reakcja polimerazy (PCR - polymerase chain reaction), również $\mathrm{w}$ wariancie ilościowym (qPCR quantitative PCR). Dla wykrywania wirusów RNA, a takie stanowią większość wirusów roślin, PCR musi być poprzedzona reakcją odwrotnej transkrypcji (RT-PCR reverse transcription-PCR). PCR umożliwia jednoczesne wykrywanie kilku wirusów (multiplex PCR/qPCR). Wśród metod opartych na reakcji PCR trzeba zwrócić uwagę na izotermalną metodę amplifikacji kwasów nukleinowych (LAMP - loop-mediated isothermal amplification). Jej zaletą jest możliwość przeprowadzania $\mathrm{w}$ warunkach stałej temperatury, w związku z czym nie wymaga specjalistycznego sprzętu i trwa od 30 do 60 minut. Uzyskanie wysokiej specyficzności reakcji jest możliwe dzięki zastosowaniu odpowiedniego zestawu par starterów.

Wprowadzenie mikromacierzy (Boonham i wsp. 2007) jest bardzo obiecujące, jednak ta metoda pozostaje wciąż zbyt kosztowna dla wykorzystywania w rutynowej praktyce.

Ważnym osiągnięciem $\mathrm{w}$ badaniach kompleksu wirusów obecnych w środowisku wodnym stała się technika diagnostyki metagenomicznej wykorzystująca sekwencjo- nowanie następnej generacji (NGS - next generation sequencing), określane również jako głębokie sekwencjonowanie (Adams i wsp. 2009; Roosinck i wsp. 2010). Metagenomika, nazywana też genomiką środowiskową lub ekogenomiką, jest nowoczesnym kierunkiem mikrobiologii. Identyfikacja patogenów polega na klonowaniu materiału genetycznego pozyskiwanego bezpośrednio $\mathrm{z}$ naturalnych środowisk, a następnie sekwencjonowaniu ogromnych bibliotek genomowych i analizie komputerowej otrzymanych danych. Użycie sekwenatorów NGS umożliwia jednoczesne poznawanie milionów sekwencji, a rozwój metod bioinformatycznych pozwala na szybką analizę uzyskanych danych. Ujawnienie sekwencji genomów określonych gatunków wirusów nie jest wprawdzie jednoznaczne z ich pełną identyfikacją, ale jest ważnym sygnałem obecności tych patogenów, a w ocenie wartości danych należy brać pod uwagę długość poznanej sekwencji genomowej oraz częstość występowania. Metagenomika umożliwia nie tylko rozpoznanie nowych gatunków wirusów, ale też bardziej dogłębną analizę ich zmienności oraz ekologii.

Ostatnio duży nacisk kładzie się na upraszczanie procedur detekcyjnych w celu ich wykorzystania bezpośrednio w miejscu pobrania próby do analizy (in-situ). Taką możliwość daje wspomniana wyżej metoda LAMP. Gutiérrez-Aguirre i wsp. (2011) opisali metodę wykorzystującą RT-qPCR wykonywaną w przenośnym termocyklerze Smart Cycler, przystosowanym do użycia w warunkach polowych, określoną jako technologia CIM (Convective Interaction Media ${ }^{\circledR}$ ).

Wyniki analiz przy użyciu nowoczesnych technik uzmysławiają potencjał mikrobiologiczny w środowisku wodnym. Szacuje się, jak podają Breitbart i Rohwer (2005), że w 200 litrach wody morskiej znajduje się 5000 różnych genotypów wirusowych, a w 1 kilogramie osadu morskiego aż milion różnych genotypów wirusów.

Pierwsze opracowanie dotyczące wykrywania wirusów roślin w różnych rodzajach wód przedstawiła Koenig (1986). Kolejny, wyczerpujący przegląd stanu wiedzy w tym zakresie opublikowały Mehle i Ravnikar (2012).

W Polsce nie prowadzono dotąd badań dotyczących identyfikacji wirusów roślin w wodach na terenach rolniczych i stąd ta problematyka jest mało poznana.

Celem niniejszej pracy było zaprezentowanie aktualnych osiągnięć światowej wirusologii związanych z wykrywaniem, identyfikacją i sposobami ograniczania ryzyka strat spowodowanych zakażeniami roślin wirusami z wody.

\section{Gatunki wirusów roślin zidentyfikowane w różnych rodzajach wód naturalnych / Plant virus species identified in different natural water sources}

Najważniejszym i najbardziej niebezpiecznym wirusem powszechnie wykrywanym w środowisku wodnym jest TMV, należący do rodzaju Tobamovirus w rodzinie Virgaviridae. Jest to patogen o wyjątkowo trwałej strukturze, bardzo szerokim zakresie roślin-gospodarzy, obejmującym około 200 gatunków roślin-gospodarzy należą- 
cych do 30 rodzin, ogromnym potencjale propagacyjnym, z łatwością przenoszący się mechanicznie bez udziału wektora i powszechnie występujący na całym świecie (Zaitlin 2000). TMV wykrywano w wodach Dunaju i Sawy (Tošic i Tošic 1984), rzekach i jeziorach w Niemczech (Koenig 1986), we Włoszech (Piazzolla i wsp. 1986), w ciekach leśnych na terenie Chorwacji (Pleše i wsp. 1996), a także w USA (Fillhart i wsp. 1998). Blisko spokrewniony z TMV wirus mozaiki pomidora (Tomato mosaic virus, ToMV) był odnajdywany w kanałach nawadniających w Słowenii (Boben i wsp. 2007), jak również, podobnie jak TMV, w wodach leśnych w USA (Jacobi i Castello 1991), a nawet stwierdzono jego obecność w wodzie chmur i mgieł (Castello i wsp. 1995). Dowodem na trwałość struktury tych gatunków jest odkrycie obecności RNA ToMV w starych lodowcach będących specyficzną przechowalnią mikroorganizmów (Castello i wsp. 1999).

TMV i ToMV zidentyfikowano ostatnio w próbach wody $\mathrm{z}$ rowów melioracyjnych i stawków w sąsiedztwie pól w południowej Wielkopolsce (Jeżewska i wsp., dane niepublikowane). Tak duża łatwość przenikania do środowiska wodnego stwarza szczególne zagrożenie dla upraw, w których stosuje się wodę w obiegu zamkniętym.

Spośród gatunków infekcyjnych wirusów roślin, zidentyfikowanych do tej pory w różnych próbach wód naturalnych na świecie, najwięcej należy do rodziny Tombusviridae. Przegląd tych wirusów przedstawiono w tabeli 1.

Wykazano też obecność w wodzie:

- wirusa X ziemniaka (Potato virus X, PVX; rodzaj Potexvirus, rodzina Alfaflexiviridae) (Büttner i Nienhaus 1989),

- wirusa mozaiki ogórka (Cucumber mosaic virus, CMV; rodzaj Cucumovirus, rodzina Bromoviridae) (Piazzolla i wsp. 1986).

Bardzo interesujące wyniki analizy metagenomicznej przeprowadzonej w celu wykrywania wirusów RNA w wodzie jeziora Needwood w USA opublikowali Djikeng i wsp. (2009). Dzięki zastosowaniu tej techniki autorzy wykryli ogółem sekwencje 200 wirusów, z czego większość, tj. 64, stanowiły wirusy roślin. Autorzy wykazali występowanie przedstawicieli następujących rodzin: Tombusviridae, Comoviridae, Partitiviridae, Bromoviridae, Luteoviridae, Flexiviridae, Tetraviridae, Tymoviridae i Sequiviridae oraz rodzajów: Tobamovirus, Umbravirus i Sobemovirus. Warto podkreślić, że w 6 przypadkach potwierdzono obecność wyżej wymienionych gatunków zidentyfikowanych w Europie, tzn. CarMV, CIRSV, CRSV, HaRV, TBSV, TMV i TNV. Nowością przedstawionych wyników jest ujawnienie obecności aż 10 wirusów zbóż pomimo, że w poprzednich doniesieniach nie raportowano o występowaniu w wodzie patogenów tej grupy roślin. Na tej liście można zauważyć podobieństwo przynależności taksonomicznej wynikającej z pozostałych badań wirusów WB, gdyż połowa $\mathrm{z}$ nich należy do rodziny Tombusviridae. Są to: wirus chlorotycznej karłowatości owsa (Oat chlorotic stunt virus, OCSV), wirus chlorotycznej pstrości kukurydzy (Maize chlorotic mottle virus, MCMV), wirus nekrotycznej smugowatości kukurydzy (Maize necrotic streak virus, MNeSV), wirus mozaiki białej linii kukurydzy (Maize white line mosaic virus, MWLMV) i wirus mozaiki prosa (Panicum mosaic virus, PMV). Trzy wirusy to przedstawiciele rodzaju Sobemovirus: wirus pstrości rajgrasu (Ryegrass mottle virus, RGMoV), wirus pstrości kupkówki (Cocksfoot mottle virus, CfMV) i wirus żółtej pstrości ryżu (Rice yellow mottle virus, RYMV). Ponadto wykryto też wirus chlorotycznej karłowatości kukurydzy (Maize chlorotic dwarf virus, MCDV), Potyviridae oraz wirus sferyczny tungro ryżu (Rice spherical tungro virus, RTSV). Powyższe dane obrazują skalę i złożoność omawianego problemu.

Badania przeprowadzone w tym samym czasie przez Rosario i wsp. (2009a) skupiły się na metagenomicznej analizie składu wirusów w wodzie po procesie jej oczyszczania ze ścieków. Autorzy przebadali próby oczyszczanej wody pobranej na Florydzie i stwierdzili w niej 1000-krotny wzrost zawartości wirusów w porównaniu $\mathrm{z}$ normalną wodą pitną. Zdecydowaną większość stanowiły wirusy bakterii (bakteriofagi), a wirusy roślin stanowiły 14\% udział w ogólnej ilości. Oprócz powszechnie występujących TMV i ToMV stwierdzono obecność 14 innych gatunków, m.in. z rodzaju Tobamovirus oraz z rodzin: Comovirdae, Potyviridae, Sequiviridae, Tombusviridae i Reoviridae.

Tak liczna obecność wirusów roślin $\mathrm{w}$ wodzie, $\mathrm{z}$ dużym udziałem zakaźnych, ma ścisły związek z odkryciem, że wirusy roślinne po przejściu przez przewód pokarmowy ludzi i zwierząt nie ulegają degradacji, ale zachowują infekcyjność (Tomlinson i wsp. 1982). Analiza metagenomiczna wirusów przeprowadzona dla fekaliów trzech zdrowych osób w USA wykazała, że najobficiej występującym wirusem okazał się wirus łagodnej pstrości papryki (Pepper mild mottle virus, PMMoV, Tobamovirus) (Zhang i wsp. 2006). Wykryto go $\mathrm{w}$ wysokim stężeniu $10^{9}$ wirionów/g suchej masy fekaliów u 66,7\% prób badanych. $\mathrm{Na}$ podstawie tych danych autorzy wywnioskowali, że osoby, u których w diecie papryka ma duży udział, znacząco przyczyniają się do rozsiewania tego wirusa. Oprócz PMMoV wykazano obecność jeszcze 34 innych gatunków, m.in. TMV, ToMV i TNV. W dalszych badaniach stwierdzono, że PMMoV może stanowić wskaźnik zanieczyszczenia wód fekaliami (Rosario i wsp. 2009b; Hamza i wsp. 2011).

\section{Wirusy z wody jako zagrożenie dla upraw roślin Water-borne viruses dangerous for plant crops}

Największe ryzyko porażeń roślin stwarzają wirusy przenikające do wody w obiegu zamkniętym, szczególnie w uprawach hydroponicznych. Pares i wsp. (1992) analizowali cyrkulację ToMV w obiegu zamkniętym roztworu składników odżywczych w uprawie hydroponicznej. Wirus przenikał do roztworu już po 3 dniach od inokulacji roślin, a poziom koncentracji wirionów wzrastał, co zapewniało dużą infekcyjność roztworu w okresie co najmniej 6 miesięcy. Również według badań Runii (1995) ToMV zalicza się do najgroźniejszych patogenów wirusowych roślin w uprawach nawadnianych w systemie zamkniętym. Ponadto autor wskazuje też na wirus zielonej 
Tabela 1. Rodzaje i gatunki infekcyjnych wirusów roślin z rodziny Tombusviridae wykryte w różnych rodzajach wód naturalnych na świecie

Table 1. Genera and species of infective plant viruses of the Tombusviridae family detected in different types of natural waters in the world

\begin{tabular}{|c|c|c|c|}
\hline $\begin{array}{l}\text { Rodzaj } \\
\text { Genus }\end{array}$ & $\begin{array}{l}\text { Gatunek } \\
\text { Species }\end{array}$ & $\begin{array}{l}\text { Pochodzenie próby wody } \\
\text { Origin of water sample }\end{array}$ & $\begin{array}{l}\text { Źródło } \\
\text { Reference }\end{array}$ \\
\hline \multirow{3}{*}{ Carmovirus } & Ahlum waterborne virus (AWBV) & $\begin{array}{l}\text { Niemcy - Germany } \\
\text { rowy w rejonach rolniczych } \\
\text { ditches in agricultural areas } \\
\end{array}$ & Yi i wsp. (1992) \\
\hline & Carnation mottle virus (CarMV) & $\begin{array}{l}\text { Niemcy - Germany } \\
\text { rzeka Oker - Oker river }\end{array}$ & Koenig i Lesemann (1985) \\
\hline & Weddel waterborne virus (WWBV) & $\begin{array}{l}\text { Niemcy - Germany } \\
\text { rowy w rejonach rolniczych } \\
\text { ditches in agricultural areas }\end{array}$ & Yi i wsp. (1992) \\
\hline Dianthovirus & Carnation ringspot virus (CRSV) & $\begin{array}{l}\text { Niemcy - Germany } \\
\text { kanał Oker Aue - Oker Aue canal }\end{array}$ & Koenig i wsp. (1988) \\
\hline Necrovirus & Tobacco necrosis virus (TNV) & $\begin{array}{l}\text { Wielka Brytania - Great Britain } \\
\text { rzeki: Tamiza, Avon, Cham, jezioro Esthwaite } \\
\text { rivers: Thames, Avon and its tributaries, Cham, } \\
\text { lake Esthwaite }\end{array}$ & Tomlinson i wsp. (1983) \\
\hline \multirow{8}{*}{ Tombusvirus } & $\begin{array}{l}\text { Carnation Italian ringspot virus } \\
\text { (CIRSV) }\end{array}$ & $\begin{array}{l}\text { Niemcy - Germany } \\
\text { stawy i strumyki leśne } \\
\text { forest ponds and streams }\end{array}$ & $\begin{array}{l}\text { Büttner i wsp. (1987), } \\
\text { Büttner i Nienhaus (1989) }\end{array}$ \\
\hline & $\begin{array}{l}\text { Grapevine Algerian latent virus } \\
\text { (GALV) }\end{array}$ & $\begin{array}{l}\text { Niemcy - Germany } \\
\text { rowy otaczające pola } \\
\text { ditches surrounding agricultural area }\end{array}$ & Yi i wsp. (1992) \\
\hline & $\begin{array}{l}\text { Havel river virus } \\
(\mathrm{HaRV})\end{array}$ & $\begin{array}{l}\text { Niemcy - Germany } \\
\text { rzeka Havel, strumyk leśny } \\
\text { Havel river, small forest stream }\end{array}$ & Koenig i wsp. (2004) \\
\hline & $\begin{array}{l}\text { Lato river virus } \\
\text { (LRV) }\end{array}$ & $\begin{array}{l}\text { Włochy - Italy } \\
\text { rzeka Lato - Lato river }\end{array}$ & Gallitelli i wsp. (1989) \\
\hline & $\begin{array}{l}\text { Neckar river virus } \\
\text { (NRV) }\end{array}$ & $\begin{array}{l}\text { Niemcy - Germany } \\
\text { rzeka Neckar - Neckar river }\end{array}$ & Koenig i Lesemann (1985) \\
\hline & $\begin{array}{l}\text { Petunia asteroid mosaic virus } \\
\text { (PeAMV) }\end{array}$ & $\begin{array}{l}\text { Niemcy - Germany } \\
\text { kanały otaczające winnice } \\
\text { ditches and draining canals surrounding vineyards }\end{array}$ & Koenig i wsp. (1989) \\
\hline & Sikte waterborne virus (SWBV) & $\begin{array}{l}\text { Niemcy - Germany } \\
\text { rowy w rejonach rolniczych } \\
\text { ditches and streams in agricultural areas }\end{array}$ & Yi i wsp. (1992) \\
\hline & Tomato bushy stunt virus (TBSV) & $\begin{array}{l}\text { Wielka Brytania - Great Britain } \\
\text { rzeki: Tamiza, Trent, Cam, jezioro Esthwaite } \\
\text { rivers: Thames, Trent, Cam, lake Esthwaite }\end{array}$ & $\begin{array}{l}\text { Tomlinson i wsp. (1983), } \\
\text { Tomlinson i Faithfull (1984) }\end{array}$ \\
\hline
\end{tabular}

*i wsp. - et al., i - and

pstrej mozaiki ogórka (Cucumber green mottle mosaic virus, CGMMV, Tobamovirus). Zwraca uwagę na istotną rolę licznie występujących w wodzie grzybów z rodzaju Olpidium (Chytridiomycota) jako wektorów wirusów, takich jak: wirus nekrotycznej plamistości melona (Melon necrotic spot virus, MNSV), wirus plamistości liści ogórka (Cucumber leaf spot virus, CLSV), czy TNV. Poważne zagrożenie $\mathrm{w}$ produkcji pomidorów $\mathrm{w}$ systemie hydroponicznym stanowi wirus mozaiki pepino (Pepino mosaic virus, PepMV), łatwo przenoszący się zarówno mechanicznie, jak też przez wektory grzybowe (Alfaro-Fernández i wsp. 2010; Schwarz i wsp. 2010).

Badania przeżywalności wirusów w wodzie w systemie hydroponicznym prowadzili Mehle i wsp. (2014). Autorzy wykazali, że PepMV zachowuje infekcyjność w wodzie o temperaturze $20^{\circ} \mathrm{C}$ do 3 tygodni, PVY (szczep NTN) do $7 \mathrm{dni}$, a wiroid wrzecionowatości bulw ziemniaka (Potato spindle tuber viroids, PSTVd) aż do 7 tygodni. Stwierdzono, że wymienione wirusy były uwalniane do wody zawierającej składniki pokarmowe $\mathrm{z}$ korzeni roślin zakażonych.

Wyniki doświadczeń przeprowadzonych przez Park’a i wsp. (1999) dotyczących TMV w systemie uprawy hydroponicznej DFC (deep flow culture) tytoniu, pomidora i papryki w kontenerach wskazywały, że główną drogą przenoszenia wirusa był kontakt bezpośredni korzeni roślin zdrowych i chorych, a nie poprzez roztwór składników pokarmowych. Rosner i wsp. (2006) opisali zakażenia wirusem plamistości liści ogórka (CLSV) w uprawie 
ogórków szklarniowych i wykazali obecność wirusa w wodzie uzdatnianej do podlewania roślin.

$\mathrm{Na}$ marginesie omawianego bezpośredniego zagrożenia dla roślin wynikającego z kontaktu z wodą niosącą wirusy, na uwagę zasługuje niedawno odkryta zależność między deficytem wody a nasileniem występowania wirusów, którą stwierdzili van Munster i wsp. (2017). Z ich badań wynika, że deficyt wody nasila przenoszenie wirusów przez wektory owadzie.

\section{Metody eliminacji wirusów z wody I Methods of virus elimination from water}

Wykazanie zagrożenia płynącego z występowania infekcyjnych wirusów w środowisku wodnym zainicjowało badania nad ich eliminacją.

Runia (1995) dokonując przeglądu możliwości oczyszczania wody w celu jej reutylizacji wymienił siedem metod. Są to metody:

- termiczna,

- ozonizacja,

- naświetlanie promieniami UV,

- filtracja na drodze powolnego przepływu przez złoże piasku (SSF - slow sand filters),

- filtracja przez membrany,

- jodynowanie,

- dezynfekcja nadtlenkiem wodoru.

Jak podaje autor w praktyce mają zastosowanie: metoda termiczna, ozonowanie oraz naświetlanie promieniami UV. Metoda filtracji przez membrany okazała się nieprzydatna $\mathrm{z}$ powodu szybkiego zatykania się porów membranowych, natomiast metoda SSF została doceniona później i rozwinięta.

Powolny przepływ wody przez złoże piasku jest najstarszym systemem jej uzdatniania, stosowanym od 1804 roku, kiedy to John Gibb zaprojektował i zbudował pierwszą oczyszczalnię wody opartą na powolnym przepływie przez złoże piasku w Paisley w Szkocji (Haig i wsp. 2011). System ten został następnie udoskonalony i zainstalowany w dużych europejskich miastach, takich jak: Paryż, Amsterdam, czy Hamburg. Jednakże na początku 20. wieku SSF utracił swoje znaczenie na rzecz szybkiego filtrowania sprzężonego z chemiczną koagulacją umożliwiającą funkcjonowanie w mniejszych gabarytach i z lepszą tolerancją zróżnicowania jakości wody. Dopiero w latach 80. ubiegłego wieku wzrosło zainteresowanie SSF głównie $z$ przeznaczeniem dla małych i średnich środowisk. Ten wzrost popularności SSF zawdzięcza swojej prostocie, niskim nakładom chemicznym i energetycznym oraz dobrej skuteczności, gdyż usuwa więcej zanieczyszczeń mikrobiologicznych w porównaniu z filtrami szybkoprzepływowymi. SSF nazywany jest filtracją biologiczną. Jego udoskonalanie przebiegało równocześnie z rozwojem mikrobiologii, a ostatnio biotechnologii środowiskowej. Złożone procesy mikrobiologiczne zachodzące podczas przepływu nie zostały jednak $\mathrm{w}$ pełni wyjaśnione $\mathrm{i}$ wymagają dalszych badań, głównie w celu możliwości interwencji i poprawiania efektywności.

Hijnen i wsp. (2004) zaprezentowali wyniki badań dotyczących skuteczności ilościowej eliminacji wirusów, bakterii i oocyst pierwotniaków metodą SSF. Efekt zatrzymywania wirusów oceniano na przykładzie bakteriofaga MS2. Po zastosowaniu metody SSF wirusy okazały się najbardziej oporne na usuwanie ze środowiska $\mathrm{w}$ porównaniu $\mathrm{z}$ bakteriami oraz pierwotniakami, ale w kolejnych latach udoskonalono system SSF i w rezultacie z powodzeniem osiągnięto eliminację TMV z wody, co dobrze rokuje dalsze sukcesy usuwania innych wirusów (Oki i wsp. 2017).

Obszerne omówienie problemu patogenów roślin w wodzie oczyszczanej, stosowanej do podlewania w szklarniach i szkółkach przestawiła Stewart-Wade (2011). Autorka najwięcej uwagi poświęciła patogenom grzybowym, ale również wskazała aktualne możliwości wykrywania i usuwania wirusów. Niestety, większość metod dezynfekcji wody $\mathrm{z}$ recyklingu, $\mathrm{z}$ powodzeniem stosowanych do pozbywania się bakterii i grzybów, takich jak działanie termiczne, naświetlanie promieniami UV, chemiczne i biologiczne, jest mało efektywna w odniesieniu do wirusów. Podstawowym warunkiem uzyskiwania czystej wody bez wirusów jest usuwanie źródeł przenikania tych patogenów czyli redukcja inokulum. Metody eliminacji wirusów obecnych w wodzie obejmują, oprócz omówionej wyżej filtracji SSF także filtrację membranową i sedymentację produktów powstających w wyniku elektro-koagulacji. Filtracja przez membrany o określonej średnicy porów jest skutecznym sposobem usuwania wirusów z wody. Liu i wsp. (1999) badali jej przydatność w odniesieniu do wirusa ToMV i wykazali, że ultrafiltracja 30K zatrzymuje 99\% wirusa obecnego w wodzie, a ultrafiltracja 5K nawet $100 \%$. Ograniczeniem stosowania tej metody w szerokiej praktyce ogrodniczej są wysokie koszty instalacji i eksploatacji. Natomiast elektro-koagulacja polegająca na przepuszczaniu w wodzie prądu elektrycznego powodującego powstawanie jonów dodatnich i ujemnych, wiążących kontaminanty o ładunkach przeciwnych, nie tylko mikroorganizmy, ale też pestycydy, metale i inne, co prowadzi do wytrącania osadów w postaci mułu, jest metodą prostą i bezpieczną, ale kosztowną i wymagającą regularnego oraz częstego usuwania szlamu.

\section{Uwagi końcowe / Final remarks}

Badania ekologiczne z wykorzystaniem najnowocześniejszych metod molekularnych ujawniły szerokie spektrum wirusów występujących we wszelkich rodzajach wód, od wody wykorzystywanej w zamkniętych systemach ogrodniczych upraw hydroponicznych, przez polowe kanały irygacyjne i melioracyjne, stawy, rzeki, jeziora, aż po morza i oceany. Większość wykrywanych wirusów ma stabilną strukturę i może zachowywać zdolność zakażania roślin nawet po dłuższym przebywaniu poza komórką gospodarza.

Wirusy mogą być uwalniane do wód melioracyjnych i gruntowych $z$ zakażonych korzeni roślin przez rozmaite zranienia i uszkodzenia oraz z rozkładających się pozostałości roślin.

Ważnym czynnikiem przetrwania wirusów roślin jest ich odporność na działanie czynników trawiennych 
w przewodzie pokarmowym ludzi i zwierząt. Dzięki tej zdolności mogą przedostawać się do rzek, jezior i innych zbiorników wodnych, z których woda jest pobierana do nawadniania. Uprawa hydroponiczna wnosi zagrożenie szybkiego rozprzestrzeniania się patogenów w całym zasięgu cyrkulacji wody.
Należy jednak podkreślić, że nie wszystkie wirusy wykrywane w wodzie zachowują zdolność zakażania roślin, dlatego detekcja metodami molekularnymi powinna być uzupełniona badaniami biologicznymi, a także systematycznym udoskonalaniem sposobów i technologii eliminacji tych patogenów z wody.

\section{Literatura / References}

Adams I.P., Gloger R.H., Monger W.A., Mumford R., Jackeviciene E., Navalinskiene M., Samuitiene M. 2009. Next-generation sequencing and metagenomic analysis: a universal diagnostic tool in plant virology. Molecular Plant Pathology 10 (4): $537-545$. DOI: 10.1111/j.1364-3703.2009.00545.x.

Alfaro-Fernández A., Cordoba-Selles M.D.C., Herrera-Vasquez J.A., Cebrian M.D.C., Jorda C. 2010. Transmission of Pepino mosaic virus by the fungal vector Olpidium virulentum. Journal of Phytopathology 158 (4): 217-226. DOI: 10.1111/j.1439-0434.2009. .01605.x.

Boben J., Kramberger P., Petrović N., Cankar K., Peterka M., Štancar A., Ravnikar M. 2007. Detection and quantification of Tomato mosaic virus in irrigation waters. European Journal of Plant Pathology 118 (1): 59-71. DOI: 10.1111/j.1439-0434.2009.01605.x.

Boonham N., Tomlinson J., Mumford R. 2007. Microarrays for rapid identification of plant viruses. Annual Review of Phytopathology 45 (1): 307-328. DOI: 10.1146/annurev.phyto.45.062806.094349.

Breitbart M., Rohwer F. 2005. Here is virus, there is virus, everywhere the same virus? Trends in Microbiology 13 (6): 278-284. DOI: 10.1016/j.yim.2005.04.03.

Büttner C., Nienhaus F. 1989. Virus contamination of waters in two forest districts of the Rhineland area (FRG). European Journal of Forest Pathology 19 (4): 206-211. DOI: 10.1111/j.1439-0329.1989.tb00254.x.

Büttner C., Jacobi V., Koenig R. 1987. Isolation of carnation Italian ringspot virus from a creek in a forested area South West of Bonn. Journal of Phytopathology 118 (2): 131-134. DOI: 10.1111/j.1439-0434.1987.tb00441.x.

Castello J.D., Lakshman D.K., Tavantzis S.M., Rogers S.O., Bachand G.D., Jagels R., Charlisle J., Liu Y. 1995. Detection of infectious Tomato mosaic tobamovirus in fog and clouds. Phytopathology 85 (11): 1409-1412.

Castello J.D., Rogers S.O., Starmer W.T., Catranis C.M., Ma L., Zhao Y., Smith J.E. 1999. Detection of tomato mosaic tobamovirus RNA in ancient glacial ice. Polar Biology 22 (3): 207-212. DOI: https://doi.org/10.1007/s003000050411.

Djikeng A., Kuzmickas R., Anderson N.G., Spiro D.J. 2009. Metagenomic analysis of RNA viruses in a fresh water lake. PLoS One 4 (9): e7264. DOI: 10.1371/journal.pone.0007264.

Fillhart R.C., Bachand G.D., Castellon J.D. 1998. Detection of infectious tobamoviruses in forest soils. Applied and Environmental Microbiology 64 (4): 1430-1435.

Gallitelli D., DiFranco A., Vovlas C., Martelli G.P. 1989. Coat protein-derived small particles in a tombusvirus from river Lato. Journal of Phytopathology 126 (3): 213-218. DOI: 10.1111/j.1439-0434.1989.tb01106.x.

Gutiérrez-Aguirre I., Steyer A., Banjac M., Kramberger P., Poljšak-Prijatelj M., Ravnikar M. 2011. On-site reverse transcription-quantitative polymerase chain reaction detection of rotaviruses concentrated from environmental water samples using methacrylate monolithic supports. Journal of Chromatography A 1218 (7): 2368-2373. DOI: 10.1016/j.chroma.2010.10.048.

Haig S.J., Collins G., Davies R.I., Dorea C.C., Quince C. 2011. Biological aspects of slow sand filtration: past, present and future. Water Science and Technology: Water Supply 11 (4): 468-472. DOI: 10.2166/ws.2011.076.

Hamza I.A., Jurzik L., Überla K., Wilhelm M. 2011. Evaluation of pepper mild mottle virus, human picornavirus and Torque teno virus as indicators of fecal contamination in river water. Water Research 45 (3): 1358-1368. DOI: https://doi.org/10.1016/j/watres. .2010 .10 .021

Hijnen W.A.M., Schijven J.F., Bonné P., Visser A., Medena G.J. 2004. Elimination of viruses, bacteria and protozoan oocysts by slow sand filtration. Water Science and Technology 50 (1): 147-154.

Jacobi V., Castello J.D. 1991. Isolation of Tomato mosaic virus from waters draining forest strands in New York State. Phytopathology 81: 1112-1117. DOI: 10.1094/Phyto-81-1112.

Koenig R. 1986. Plant viruses in rivers and lakes. Advances in Virus Research 31: 321-333. DOI: https://doi.org/10.1016/S0065-3527(08)60267-5.

Koenig R., An D., Lesemann D.E., Burgermeister W. 1988. Isolation of carnation ringspot virus from a canal near a sewage plant: cDNA hybridization analysis, serology and cytopathology. Journal of Phytopathology 121 (4): 346-356. DOI: 10.1111/j.1439-0434. 1988.tb00978.x.

Koenig R., Lesemann D.E. 1985. Plant viruses in German rivers and lakes. I. Tombusviruses, a potexvirus and carnation mottle virus. Journal of Phytopathology 112 (2): 105-116. DOI: 10.1111/j.1439-0434.1985.tb04819.x.

Koenig R., Pfeilstetter E., Kegler H., Lesemann D.E. 2004. Isolation of two strains of a new Tombusvirus (Havel river virus, HaRV) from surface waters in Germany. European Journal of Plant Pathology 110 (4): 429-433. DOI: https:/doi.org/10.1023/ /B:EJPP.0000021084.38938.c3.

Koenig R., Rüdel M., Lesemann D.E. 1989. Detection of petunia asteroid mosaic, carnation ringspot and tobacco necrosis viruses in ditches and drainage canals in a grapevine-growing area in West Germany. Journal of Phytopathology 127 (2): 169-172. DOI: 10.1111/j.1439-0434.1989.tb01125.x.

Liu M., Lau A.K., Lo K.V. 1999. Ultrafiltration tests for the reutilization of greenhouse wastewater. Journal of Environmental Science and Health, Part B, Pesticides, Food Contamination, and Agricultural Wastes 34 (6): 1101-1110. DOI: http://dx.doi.org/10.1080/ /03601239909373247.

Mehle N., Gutiérrez I., Prezelj N., Delic D., Vidic U., Ravnikar M. 2014. Survival and transmission of Potato virus Y, Pepino mosaic virus, and Potato spindle tuber viroid in water. Applied and Environmental Microbiology 80 (4): 1455-1462. DOI: http://dx.doi.org/10.1128/AEM.03349-13. 
Mehle N., Ravnikar M. 2012. Plant viruses in aqueous environment - Survival, water mediated transmission and detection. Water Research 46 (16): 4902-4917. DOI: 10.1016/j.watres.2012.07.027.

Oki L.R., Bodaghi S., Lee E., Haver D., Pitton B., Nackley L., Mathews D.M. 2017. Elimination of Tobacco mosaic virus from irrigation runoff using slow sand filtration. Scientia Horticulturae 217: 107-113. DOI: http://dx.doi.org/101016/j.scienta. .2017.01.036.

Pares R.D., Gunn L.V., Cresswell G.C. 1992. Tomato mosaic virus infection in recirculating nutrient solution. Journal of Phytopathology 135 (3): 192-198. DOI: 10.1111/j.1439-0434.1992.tb01266.x.

Park W.M., Lee G.P., Ryu K.H., Park K.W. 1999. Transmission of tobacco mosaic virus in recirculating hydroponic system. Scientia Horticulturae 79 (3-4): 217-226. DOI: 10.1016/S0304-4238(98)00215-5.

Piazzolla P., Castellano M.A., De Stradis A. 1986. Presence of plant viruses in some rivers of southern Italy. Journal of Phytopathology 116 (3): 244-246. DOI: 10.1111/j.1439-0434.1986.tb00917.x.

Pleše N., Juretic N., Mamula D., Polák Z., Krajačiċ M. 1996. Plant viruses in soil and water of forest ecosystems in Croatia. Phyton (Horn, Austria) 36 (1): 135-143.

Riley M.R., Gerba C.P., Eimelech M. 2011. Biological approaches for addressing the grand challenge of providing access to clean drinking water. Journal of Biological Engineering 5 (2): 1-10. DOI: https://doi.org/10.1186/1754-1611-5-2.

Roosinck M.J., Saha P., Wiley G.B., Quan J., White J.D., Lai H., Chavarria F., Shen G., Roe B.A. 2010. Ecogenomics: using massively parallel pyrosequencing to understand virus ecology. Molecular Ecology 19 (s1): 81-88. DOI: 10.1111/j.1365-294X.2009.04470.x.

Rosario K., Nilsson C., Lim Y.W., Ruan Y., Breitbart M. 2009a. Metagenomic analysis of viruses in reclaimed water. Environmental Microbiology 11 (11): 2806-2820. DOI: 10.1111/j.1462-2920.2009.01964.x.

Rosario K., Symonds E.M., Sinigalliano C., Stewart J., Breitbart M. 2009b. Pepper mild mottle virus as an indicator of fecal pollution. Applied and Environmental Microbiology 75 (22): 7261-7267. DOI: 10.1128/AEM.00410-09.

Rosner A., Lachman O., Pearlsman M., Feigelson L., Meslenin L., Antignus Y. 2006. Characterization of cucumber leaf spot virus isolated from recycled irrigation water of soil-less cucumber cultures. Annals of Applied Biology 149 (3): 313-316. DOI: 10.1111/j.1744-7348.2006.00096.x.

Runia W.T. 1995. A review of possibilities for disinfection and recirculation water from soilless cultures. Acta Horticulturae 382: 221-229. DOI: 10.17660/ActaHortic.1995.382.25.

Schwarz D., Beuch U., Bandte M., Büttner C., Obermeister C. 2010. Spread and interaction of Pepino mosaic virus (PepMV) and Pythium aphanidermatum in a closed nutrient solution recirculating system: effects on tomato growth and yield. Plant Pathology 59 (3): 443-452. DOI: 10.1111/j.1363059.2009.02229.x.

Stewart-Wade S.M. 2011. Plant pathogens in recycled irrigation water in commercial plant nurseries and greenhouses: their detection and management. Irrigation Science 29 (4): 267-297. DOI: 10.1007/s00271-011-0285-1.

Tomlinson J.A., Faithfull E.M. 1984. Studies on the occurrence of tomato bushy stunt virus in English rivers. Annals of Applied Biology 104 (3): 485-495. DOI: 10.1111/j.1744-7348.1984.tb03031.x.

Tomlinson J.A., Faithfull E.M., Flewett T.H., Beards G. 1982. Isolation of infective Tomato bushy stunt virus after passage through the human alimentary tract. Nature 300: 637-638. DOI: 10.1038/300637a0.

Tomlinson J.A., Faithfull E.M., Webb M.J.W., Fraser R.S.S., Seeley N.D. 1983. Chenopodium necrosis: a distinctive strain of tobacco necrosis virus isolated from river water. Annals of Applied Biology 102 (1): 135-147. DOI: 10.1111/j.1744-7348.1983.tb02674.x.

Tošic M., Tošic D. 1984. Occurrence of tobacco mosaic virus in water of the Danube and Sawa rivers. Journal of Phytopathology 110 (3): 200-202. DOI: 10.1111/j.1439-0434.1984.tb00748.x.

van Munster M., Yvon M., Vile D., Dader B., Fereres A., Blanc S. 2017. Water deficit enhances the transmission of plant viruses by insect vectors. PLoS One 12 (5): e0174398. DOI: 10.1371/journal.pone.0174398. eCollection 2017.

Wolf M. 2015. Wirusy w wodzie - zagrożenia i metody kontroli. PBN Report, 11 ss.

Yarwood C.E. 1960. Release and preservation of virus by roots. Phytopathology 50 (2): 111-114.

Yi L., Lesemann D.E., Koenig R., Rüdel M., Pfeilstetter E. 1992. Isometric plant viruses in ditches and streams in agricultural areas: recovery of previously found viruses and identification of hitherto unrecorded carmo- and tombusviruses including grapevine Algerian latent virus. Journal of Phytopathology 134 (2): 121-132. DOI: 10.1111/j.1439-0434.1992.tb01221.x.

Zaitlin M. 2000. Tobacco mosaic virus. Description of Plant Viruses No 370, 4 pp.

Zhang T., Breitbart M., Lee W.H., Run J.Q., Wei C.I., Soh S.W.I., Hibberd M.I., Liu E.T., Rohwer F., Ruan Y. 2006. RNA viral community in human feces: prevalence of plant pathogenic viruses. PLoS Biology 4 (1): e3. DOI: https://doi.org/10.1371/ /journal.pbio.0040003. 